\title{
CONTEXTUAL TEACHING AND LEARNING DALAM PENDIDIKAN AGAMA ISLAM
}

\author{
KISMATUN \\ SMP N 1 Limpung \\ e-mail: kismatunazza@gmail.com
}

\begin{abstract}
ABSTRAK
Makalah ini bertujuan memberi perhatian kepada pengembangan Pendidikan Agama Islam berbasis teori Contextual Teaching and Learning (CTL) sebagai solusi dari krisis yang dialami Pendidikan Agama Islam. Kenyataannya, Pendidikan Agama Islam dikesampingkan di sekolah umum karena menggunakan metode pembelajaran konvensional yang membosankan dan tidak memberi produk pendidikan yang signifikan. Penelitian sebelumnya menemukan bahwa akurasi pembelajaran konvensional berbasis ceramah hanya memberi $11 \%$ tingkat kebermaknaan bagi siswa. Kenyataan ini berbanding terbalik dengan teori CTL atau pembelajaran dan pengajaran kontekstual yang menekankan kontekstualisasi pengetahuan. Pada akhirnya, penelitian ini menemukan pembelajaran $C T L$ menekankan kepada proses keterlibatan peserta didik untuk menemukan materi yang dipelajari dan menghubungkan dengan situasi kehidupan nyata. Model pembelajaran ini mendorong peserta didik untuk dapat menerapkannya dalam kehidupan sehari-sehari. Terdapat enam karakteristik pembelajaran CTL, yaitu: pembelajaran bermakna, penerapan pengetahuan, berpikir tingkat tinggi, kurikulum yang dilambangkan berdasarkan standar, reponsif terhadap kebudayaan, dan penilaian autentik. Selain itu, CTL memiliki tujuh asas yang melandasi pelaksanaan proses pembelajaran menggunakan model pembelajaran CTL, yaitu: konstruktivisisme, inquiry, bertanya, masyarakat belajar, modelling, refleksi, dan penilaian nyata. Pembelajaran CTL sangat diperlukan terutama dalam upaya pengembangan pendidikan agama Islam, karena bersifat mengajak peserta didik lebih aktif dalam pembelajaran.
\end{abstract}

Kata Kunci: kontekstual, pembelajaran, pengajaran, Pendidikan Agama Islam, Pengembangan pendidikan

\section{ABSTRACT}

This paper aims to pay attention to the development of Islamic education based on Contextual Teaching and Learning (CTL) theory as a solution to the crisis experienced by Islamic education. In fact, Islamic education is sidelined in public schools because it uses conventional learning methods that are boring and do not provide a significant educational product. Previous research found that the accuracy of lecture-based conventional learning only gave $11 \%$ level of meaning for students. This fact is in contrast to the theory of CTL or contextual learning and teaching which emphasizes the contextualization of knowledge. In the end, this study found that CTL learning emphasizes the process of involving students in finding the material being studied and connecting it to real-life situations. This learning model encourages students to be able to apply it in everyday life. There are six characteristics of CTL learning, namely: meaningful learning, application of knowledge, higher order thinking, curriculum which is symbolized by standards, responsiveness to culture, and authentic assessment. In addition, CTL has seven principles that underlie the implementation of the learning process using the CTL learning model, namely: constructivism, inquiry, questioning, learning community, modeling, reflection, and real assessment. CTL learning is very necessary, especially in efforts to develop Islamic education, because it invites students to be more active in learning.

Keywords: Contextual, Teaching, Learning, Islamic Education, Developing Education

\section{PENDAHULUAN}

Mata pelajaran Pendidikan Agama Islam sering dianggap tidak penting atau pelajaran tambahan yang menghabiskan waktu. Kenyataannya mata pelajaran pendidikan agama Islam kalah berkontes dengan pelajaran ilmu pengetahuan umum, seperti Matematika, Fisika, Kimia, 
Biologi, dan sebagainya. Hal ini terjadi karena guru pendidikan agama Islam menggunakan metode pembelajaran konvensional, seperti ceramah. Oleh karenanya, dibutuhkan upaya untuk meningkatkan mutu pembelajaran agama Islam sebagai solusi dari kejumudan pendidikan Agama Islam selama ini. Di antara solusi tersebut adalah pencarian metode pembelajaran baru misalnya pengembangan metode pembelajaran menggunakan teori Contextual Teaching and Learning (CTL).

CTL adalah konsep mengajar dan pembelajaran yang membantu pendidik menghubungkan isi subjek dengan situasi dunia nyata; artinya, peserta didik dituntut untuk dapat menangkap hubungan antara pengalaman belajar di sekolah dengan kehidupan nyata dengan memotivasi siswa untuk membuat hubungan antara pengetahuan dan penerapannya (Hudson dan Whisler, 2008: 54; Lestari, 2017: 414). Kelebihan Pembelajaran CTL ini melibatkan peserta didik secara penuh dalam proses pembelajaran, sehingga proses pembelajaran didasarkan pada pencarian dan penemuan melalui proses berpikir secara sistematis. Pengetahuan bukanlah sejumlah fakta hasil dari mengingat, akan tetapi merupakan hasil dari proses menemukan sendiri (Tamam, 2015: 90).

Pembelajaran CTL mengarahkan peserta didik kepada proses pemecahan masalah, sebab dengan memecahkan masalah anak berkembang secara untuh bukan hanya intelektualnya tetapi juga mental dan emosionalnya (Hamruri, 2009: 173-175). Belajar CTL ini memacu peserta didik untuk berperan aktif dalam proses pembelajaran dan mengajak peserta didik untuk belajar dari kehidupan peserta didik sehari-hari (Desiani dan Yunita, 2017: 189).

CTL memberi jalan menuju akademik yang unggul karena mengkaitkan materi pelajaran dengan kehidupan nyata. Metode ini mempermudah proses mengingat suatu materi, sehingga pemahaman terhadap materi lebih mudah diingat dan sulit untuk dilupakan serta sesuai dengan pembelajaran berbasis kompetensi. Oleh karena itu, pembelajaran dengan menggunakan pendekatan CTL ini dipandang sesuai untuk diterapkan di sekolah terutama untuk mata pelajaran PAI (Harudin, 2018: 122).

\section{METODE PENELITIAN}

Penelitian ini tergolong sebagai penelitian kualitatif yang mencoba melakukan investigasi berbasis pustaka. Penelitian menawarkan solusi bagi model pembelajaran konvensional yang terbelakang dan tidak memberi pengaruh signfikan dengan menawarkan model pembelajaran kontekstual. Harapannya, penelitian ini berkontribusi pada pengembangan pendidikan agama Islam agar tidak lagi dikesampingkan di sekolah umum. Data yang diperlukan dalam penelitian ini adalah data primer dan sekunder. Data primer diperoleh melalui sumber pertama, yaitu pustaka yang memberi ulasan mengenai teori pembelajaran kontekstual dan thesis-thesis mengenai pengembangan pendidikan Agama Islam selama ini (Andi Prastowo, 2016: 204). Adapun data sekunder diperoleh dari sumber kedua, ketiga, dan seterusnya yang merupakan data pelengkap sekaligus pendukung data primer yang diperoleh melalui data yang terdapat dalam literatur kepustakaan seperti buku, jurnal, artikel, maupun internet (Andi Prastowo, 2016: 205. Data sekunder dalam penelitian ini berupa dokumen-dokumen dan buku-buku yang berkaitan dengan pendidikan Agama Islam dan teori pembelajaran kontekstual.

Penelitian mendeskripsikan secara ontologi, epistemologi dan aksiologi teori pembelajaran CTL dalam pendidikan Agama Islam. Asumsi dasar tersebut penulis wujudkan dalam langkah operasional berikut: pertama, penulis mendefinisikan CTL guna mengetahui keluasan kajiannya. Kedua, penulis mendeskripsikan karakteristik Perbedaan CTL dengan pembelajaran konvensional yang berkembang sebelumnya. Ketiga, penulis mendeskripsikan peran pendidik dan peserta didik dalam CTL. Keempat, penulis mendeskripsikan pola dan tahapan CTL dalam pembelajaran pendidikan Agama Islam. Kelima, penulis mendeskripsikan penilaian dalam pembelajaran kontekstual. Pada akhirnya, penelitian ini dilakukan guna melakukan pengembangan pembelajaran mata pelajaran pendidikan Agama Islam yang mengalami krisis. 


\section{HASIL DAN PEMBAHASAN}

\section{Hasil Penelitian}

Berikut adalah hasil penelitian berdasar study pustaka mengenai CTL terhadap pendidikan Agama Islam:

\begin{tabular}{|c|c|c|c|}
\hline $\mathrm{No}$ & Artikel Penelitian & Temuan & Refleksi \\
\hline 1 & $\begin{array}{l}\text { Aplikasi Metode Contextual } \\
\text { Teaching Learning (CTL) } \\
\text { Dalam Pembelajaran PAI } \\
\text { (Saputra, 2014) }\end{array}$ & $\begin{array}{l}\text { PAI gagal membekali siswa } \\
\text { untuk memecahkan persoalan } \\
\text { kehidupan jangka panjang dan } \\
\text { pengamalan nilai Agama } \\
\text { Islam. Berdasarkan latar } \\
\text { belakang tersebut, maka } \\
\text { dibutuhkan penerapan dan } \\
\text { pengaruh konsep CTL pada } \\
\text { PAI. Hasil penelitian } \\
\text { menunjukkan kemampuan dan } \\
\text { pengembangan prestasi siswa } \\
\text { mengalami peningkatan } \\
\text { setelah pembelajaran } \\
\text { dilakukan menggunakan } \\
\text { metode CTL. }\end{array}$ & $\begin{array}{lr}\text { CTL terbukti berhasil } \\
\text { menyelesaikan } & \text { krisis } \\
\text { yang terjadi } & \text { pada } \\
\text { pembelajaran } & \text { PAI } \\
\text { yang } & \text { gagal } \\
\text { menanamkan } & \text { nilai } \\
\text { agama Islam } & \text { dan } \\
\text { membekali siswa } \\
\text { untuk menyelesaikan } \\
\text { masalah } & \text { jangka } \\
\text { panjang. } & \end{array}$ \\
\hline 2 & $\begin{array}{lll}\begin{array}{l}\text { Contextual } \\
\text { Learning (CTL) }\end{array} \text { Dalaming } \\
\text { Pembelajaran PAI } \\
\text { 2011) }\end{array}$ & $\begin{array}{l}\text { CTL adalah pendekatan } \\
\text { pembelajaran yang lebih } \\
\text { memberi perhatian kepada } \\
\text { kemampuan mengkonstruksi } \\
\text { pengetahuan. Sementara PAI } \\
\text { adalah mata pelajaran yang } \\
\text { lebih banyak menghafal. } \\
\text { Berdasar latar belakang } \\
\text { demikian utuh usaha untuk } \\
\text { mengelaborasi teori } \\
\text { pembelajaran CTL dalam PAI. } \\
\text { Temuan penelitian adalah } \\
\text { pembelajaran PAI } \\
\text { menggunakan CTL terbukti } \\
\text { meningkatkan pemahaman } \\
\text { moral dan afektif anak yang } \\
\text { didapat melalui pengalaman } \\
\text { pribadi. }\end{array}$ & $\begin{array}{l}\text { CTL merubah PAI } \\
\text { sebagai mata } \\
\text { pelajaran yang hanya } \\
\text { menghafal menjadi } \\
\text { mata pelajaran yang } \\
\text { berbasi pengalaman } \\
\text { kontekstual. }\end{array}$ \\
\hline 3 & $\begin{array}{l}\text { Bambang Sutedja, Penerapan } \\
\text { Pendekatan Pembelajaran } \\
\text { Kontekstual Dalam } \\
\text { Pendidikan Agama Islam Di } \\
\text { Universitas Pendidikan } \\
\text { Indonesia (Parhan, 2019) }\end{array}$ & $\begin{array}{l}\text { Dibutuhkan pembelajaran } \\
\text { yang lebih fokus, fresh, } \\
\text { menyenangkan dan bermakna, } \\
\text { sementara itu, pembelajaran } \\
\text { PAI membosankan dan tidak } \\
\text { bermakna. Dari latar belakang } \\
\text { tersebut, butuh pengembangan } \\
\text { pendidikan menggunakan } \\
\text { CTL untuk meningkatkan } \\
\text { mutu pembelajaran PAI. } \\
\text { Penelitan ini menemukan } \\
\text { bahwa CTL terbukti } \\
\text { meningkatkan hasil belajar, } \\
\text { dari 33,33\% menjadi 82,05\%. }\end{array}$ & $\begin{array}{l}\text { CTL mampu } \\
\text { merubah PAI yang } \\
\text { membosankan } \\
\text { menjadi lebih } \\
\text { menyenangkan dan } \\
\text { kontekstual dan } \\
\text { terbukti } \\
\text { meningkatkan hasil } \\
\text { belajar dari } 33,33 \% \\
\text { menjadi } 82,05 \% \text {. }\end{array}$ \\
\hline
\end{tabular}




\begin{tabular}{|c|c|c|}
\hline & $\begin{array}{l}\text { Pengembangan Desain } \\
\text { Pembelajaran Dengan Model } \\
\text { Contextual Teaching and } \\
\text { Learning Pada Pelajaran } \\
\text { Pendidikan Agama Islam } \\
\text { Siswa Kelas VII Smp Negeri } \\
2 \text { Asembagus (Hadi, 2016) }\end{array}$ & \begin{tabular}{lrlr} 
Dibutuhkan usaha untuk & \multicolumn{2}{l}{ CTL menegaskan PAI } \\
menegaskan PAI sebagai & sebagai konsep dasar \\
konsep dasar dan terapan & pembelajaran r & al- \\
ajaran normatif Al-Qur'an dan & Qur'an dan Hadits \\
al-Hadits; sementara itu, posisi & secara normatif yang \\
PAI tidak jelas dan kurang & membantu & dan \\
bermutu. Berdasar latar & memudahkan & guru \\
belakang tersebut, dibutuhkan & dengan & \\
pengembangan pendidikan & ditunjukkannya oleh \\
menggakan CTL. Dari hasil & SPSS 16.0. \\
penelitian, ditemukan CTL & \\
membantu dan memudahkan & \\
guru dalam pembelajaran PAI & \\
yang ditunjukkan oleh SPSS & \\
16.0. & &
\end{tabular} \\
\hline & $\begin{array}{l}\text { Pengembangan perangkat } \\
\text { pembelajaran pendidikan } \\
\text { agama Islam model Problem } \\
\text { Based Learning dengan } \\
\text { pendekatan Contextual } \\
\text { Teaching and Learning untuk } \\
\text { meningkatkan kemampuan } \\
\text { berpikir kreatif siswa } \\
\text { (Nurhidayah, 2019). }\end{array}$ & $\begin{array}{lrl}\text { Problem-Based Learning } & \text { Pendekatan berbasis } \\
\text { melalui pendekatan } & \text { penyelesaian masalah } \\
\text { kontekstual berpengaruh } & \text { terbukti memberi } \\
\text { positif terhadap capaian } & \text { hasil yang signifikan } \\
\text { belajar siswa. Penelitian ini } & \text { dalam pengembangan } \\
\text { menemukan efektifitas nilai } & \text { pembelajaran PAI } \\
\text { rata-rata yang dicapai melalui } & \\
\text { pendekatan ini sebesar 93,94\% } & \\
\text { yang semula 3,75. } & \end{array}$ \\
\hline & $\begin{array}{lr}\text { Implementasi } & \text { Model } \\
\text { Contextual Teaching } & \text { And } \\
\text { Learning } & \text { untuk } \\
\text { Meningkatkan } & \text { Prestasi } \\
\text { belajar Pendidikan } & \text { Agama } \\
\text { Islam, (Purnomo, dkk., 2020) }\end{array}$ & 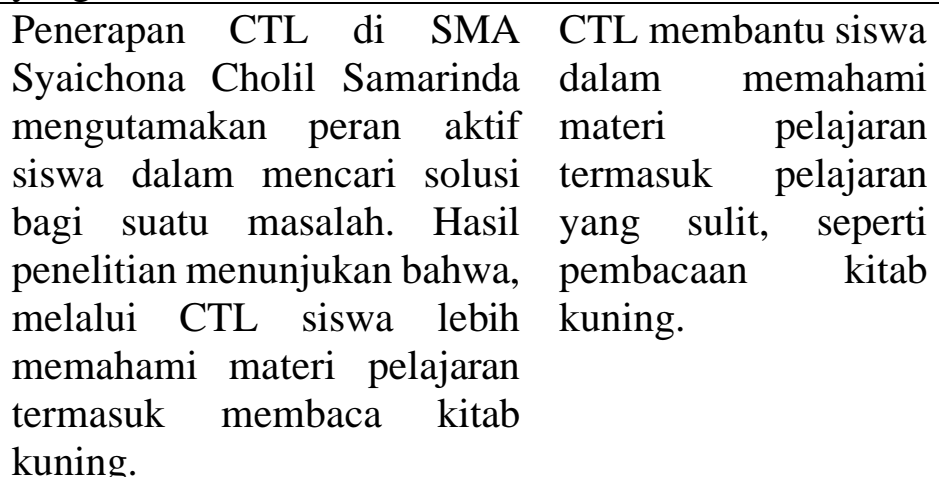 \\
\hline
\end{tabular}

\section{Contextual Teaching and Learning}

Kata contextual berasal dari kata contex, yang berarti "konteks, suasana atau keadaan". Dengan demikian, contextual diartikan "yang berhubungan dengan suasana." (Hamruni, 2015: 178). CTL dapat diartikan sebagai suatu pembelajaran yang berhubungan dengan susana tertentu (Glynn, 2004: 51). Pembelajaran CTL (Contextual teaching and learning) adalah konsepsi pengajaran dan pembelajaran yang membantu pendidik menghubungkan antara materi pelajaran dengan situasi dunia nyata dan memotivasi peserta didik untuk membuat koneksi antara pengetahuan dan penerapannya dalam kehidupan mereka sebagai anggota keluarga dan masyarakat (Berns dan Erickson, 2001: 3; Rusman, 2016: 190).

CTL dipengaruhi oleh filsafat kontrutivisme yang digagas oleh Mark Baldwin dan dikembangkan oleh Jean Piaget. Aliran filsafat konstruktivisme berangkat dari pemikiran epistimologi Giambatista Vico (Sanjaya, 2006: 256-257). Makna "mengetahui", menurut Vico, adalah mengerti cara membuat sesuatu; seseorang dikatakan mengetahui ketika ia mampu menjelaskan unsur pembangun sesuatu. Pendangan filsafat kontrutivisme tentang hakikat pengetahuan mempengaruhi konsep proses belajar, bukan menghafal, tetapi mengkontruksi pengetahuan melalui pengalaman. Pengetahuan bukanlah hal yang diberi oleh orang lain, tetapi hasil proses mengkonstruksi oleh individu (Hamruri, 2009: 175). 
Pembelajaran kontekstual membekali peserta didik dengan pengetahuan fleksibel yang dapat diterapkan dari permasalahan ke permasalahan lain (Zulfatmi, 2018: 29). CTL mengaitkan informasi dan pengetahuan awal yang dimiliki peserta didik dengan sisitem penilaian autentik melalui penerapan praktis dalam memecahkan masalah (Faturrahman, 2012: 74-74).

Karakteristik Contextual Teaching and Learning

The Nort West Regional Education Laboratory USA mengemukakan ada enam karakteristik pembelajaran CTL:

a. Pembelajaran bermakna: pemahaman, relevasi, dan penilaian privadi sangat terkait dengan kepentingan peserta didik dalam mempelajari isi materi pelajaran. Pembelajaran dirasa terkait dengan kehidupan nyata atau peserta didik mengerti manfaat isi pembelajaran. Jika mereka merasa berkepentingan umum belajar demi masa yang akan datang.

b. Penerapan pengetahuan: kemampuan peserta didik untuk memahami apa yang dipelajari dan diterapkan dalam tatanan kehidupan dan fungsi di masa sekarang atau dimasa yang akan datang.

c. Berpikir tingkat tinggi: peserta didik diwajibkan untuk memanfaatkan berpikir berfikir kreatif dalam pengumpulan data, pemahaman suatu isu dan pemecahan suatu masalah.

d. Kurikulum yang dilambangkan berdasarkan standar. Isi pembelajaran harus dikaitkan dengan standar lokal (provinsi), nasional, perkembangan pengetahuan, dan teknologi.

e. Reponsif terhadap kebudayaan: pendidik harus memahami dan menghargai nilai kepercayaan, dan kebiasaan peserta didik, teman, pendidik dan masyarakat dimana dia mendapatkan pendidikan.

f. Penilaian autentik: penggunaan berbagai penilaian misalnya penilaian tugas terstruktur, kegiatan peserta didik, penggunaan portofolio, dan sebagainya akan merepleksikan hasil besar sesungguhnya (Fatrhurrahman dan Sulistyorini 2012: 75-76).

Perbedaan Contextual Teaching and Learning dengan Pembelajaran Konvensional

Perbedaan pokok antara pembelajaran CTL dan pembelajaran konvensional adalah:

a. CTL menempatkan peserta didik sebagai subjek belajar, artinya peserta didik berperan aktif dalam setiap pembelajaran dengan cara menemukan dan menggali sendiri materi pembelajaran. Sedangkan pada pembelajaran konvensional peserta didik ditempatkan sebagai obyek belajar yang berperan sebagai penerima informasi secara pasif.

b. Dalam pembelajaran CTL, peserta didik belajar melalui kegiatan kelompok, seperti kerja kelompok, diskusi, saling menerima, dan memberi. Sedangkan dalam pembelajaran konvensional peserta didik banyak belajar secara individual dengan menerima, mencatat, dan menghafal materi pelajaran.

c. Dalam CTL, pembelajaran dikaitkan dengan kehidupan nyata secara riil, sedangkan dalam pembelajaran konvensional, pembelajaran bersifat teoritis dan abstrak.

d. Dalam CTL, kemampuan didasarkan atas pengalaman, sedangkan dalam pembelajaran konvensional kemampuan diperoleh melalui latihan-latihan.

e. Tujuan akhir dari proses pembelajaran melalui CTL adalah kepuasan diri, sedangkan dalam pembelajaran konvensional, tujuan akhir adalah nilai atau angka (Sanjaya, 2006: 260-261).

f. Dalam CTL, tindakan atau perilaku dibangun atas kesadaran diri sendiri, misalnya individu tidak melakukan perilaku tertentu karena ia menyadari bahwa perilaku itu merugikan dan tidak bermanfaat, sedangkan dalam pembelajaran konvensional, tindakan atau perilaku individu tidak melakukan sesuatu disebabkan takut hukuman atau sekedar untuk memperoleh angka atau nilai dari pendidik.

g. Dalam CTL, pengetahuan yang dimiliki setiap individu selalu berkembang sesuai dengan pengalaman yang dialaminya, oleh sebab itu setiap peserta didik bisa terjadi perbedaan dalam memaknai hakikat pengetahuan yang dimilikinya. Dalam pembelajaran konvensional hal ini tidak mungkin terjadi. Kebenaran yang dimiliki bersifat absolut dan final, oleh karena pengetahuan dikonstruksi oleh orang lain. 
h. Oleh karena tujuan yang ingin dicapai adalah seluruh aspek perkembangan peserta didik, maka dalam CTL keberhasilan pembelajaran diukur dengan berbagai cara, misalnya dengam evaluasi proses, hasil karya peserta didik, penambilaan, rekaman, observasi, wawancara, dan lain sebagainya, sedangkan dalam pembelajaran konvensional keberhasilan pembelajaran biasanya hanya diukur dari tes (Fathurrohman dan Sulistyorini, 2012: 82-83).

\section{Peran Pendidik dan Peserta Didik dalam Contextual Teaching and Learning}

Setiap peserta didik memiliki gaya yang berbeda dalam belajar. Perbedaan yang dimiliki peserta didik tersebut oleh Bobbi Deporter yang dikutip dalam buku berjudul "Strategi Pembelajaran" karya Wina Sanjaya, dinamakan sebagai unsur modalitas belajar. Menurutnya ada 3 (tiga) tipe gaya belajar peserta didik, yaitu tipe visual (gaya belajar dengan cara melihat, artinya peserta didik akan lebih cepat belajar dengan cara menggunakan indra penglihatannya), tipe audiotorial (tipe belajar dengan cara menggunakan alat pendengaran), dan tipe kinestetis (tipe belajar dengan cara bergerak, bekerja, dan menyentuh).

Dalam proses pembelajaran kontekstual, setiap pendidik perlu memahami tipe belajar dalam dunia peserta didik, artinya pendidik perlu menyesuaikan gaya mengajar terhadap gaya belajar peserta didik. Sehubungan dengan hal ini, terdapat beberapa hal yang harus diperhatikan bagi setiap pendidik dalam menggunakan pendekatan $C T L$.

a. Pendidik dalam pembelajaran $C T L$ dipandang sebagai individu yang sedang berkembang. Kemampuan belajar seseorang akan dipengaruhi oleh tingkat perkembangan dan keluasan pengalaman yang dimilikinya. Anak bukanlah orang dewasa dalam bentuk kecil, melainkan organisme yang sedang berada dalam tahap-tahap perkembangan. Kemampuan belajar akan sangat ditentukan oleh tingkat perkembangan dan pengalaman mereka. Dengan demikian, peran pendidik harus bisa membimbing peserta didik agar mereka bisa belajar sesuai dengan tahap perkembangannya.

b. Setiap peserta didik memiliki kecenderungan untuk belajar hal-hal yang baru dan penuh tantangan. Kegemaran peserta didik adalah mencoba hal-hal yang dianggap aneh dan baru. Oleh karena itulah belajar bagi mereka adalah mencoba memecahkan setiap persoalan yang menantang. Dengan demikian, pendidik berperan dalam memilih bahan-bahan belajar yang danggap penting untuk dipelajari oleh peserta didik.

c. Belajar bagi peserta didik adalah proses mencari keterkaitan atau keterhubungan antara hal-hal yang baru dengan hal-hal yang sudah diketahui. Dengan demikian, peran pendidik adalah membantu agar setiap peserta didik mampu menemukan keterkaitan antara pengalaman baru dengan pegalaman sebelumnya.

d. Belajar bagi anak adalah proses menyempurnakan skema yang telah ada (asimilasi) atau proses pembentikan skema baru (akomodasi). Dengan demikian, tugas pendidik adalah menfasilitasi peserta didik melakukan asimilasi dan akomodasi (Sanjaya, 2006: 262-263).

\section{Penerapan Contextual Teaching and Learning di Kelas}

CTL memiliki tujuh asas yang melandasi pelaksanaan proses pembelajaran dengan menggunakan model pembelajaran kontekstual. Sering kali asa ini disebut juga komponenkomponen $C T L$.

a. Konstruktivisisme

Pada dasarnya, pembelajaran melalui $C T L$ mendorong agar peserta didik bisa mengkonstruksi pengetahuannya melalui proses pengamatan dan pengalaman. Sebab pengetahuan hanya akan fungsional manakala dibangun oleh individu. pengetahuan yang hanya diberikan tidak akan menjadi pengetahuan yang bermakna (Riyanto, 2010: 169).

b. Inquiry

Asas inkuiri merupakan proses pembelajaran berdasarkan pada pencarian dan penemuan melalui proses berpikir secara sistematis. Pengetahuan bukanlah sejumlah fakta hasil dari mengingat, akan tetapi hasil dari proses menemukan sendiri. Menemukan merupakan kegiatan inti dari proses pembelajaran Kontekstual (Marzuki, 2000: 105). Dengan demikian, dalam proses perencanaan, pendidik bukanlah mempersiapkan sejumlah materi 
yang harus dihafal, melainkan merancang pembelajaran yang memungkinkan peserta didik dalam menemukan sendiri materi yang harus dipahaminya (Hamruri, 2009: 182).

c. Bertanya

Bertanya adalah strategi utama dalam pembelajaran kontekstual. Bertanya dalam pembelajaran dipandang sebagai kegiatan pendidik untuk mendorong, membimbing, dan menilai kemampuan berpikir peserta didik. Dengan bertanya peserta didik dapat menggali informasi, mengkonfirmasikan apa yang sudah diketahui. Dan mengarahkan perhatian pada aspek yang belum diketahui (Akbar, 2015: 219). Menurut Wina Sanjaya (2006: 266) dalam pembelajaran yang produktif kegiatan bertanya akan sangat berguna untuk:

1) Menggali informasi tentang kemampuan peserta didik dalam penugasan materi pelajaran

2) Membangkitkan motivasi belajar peserta didik

3) Merangsang keingintahuan peserta didik terhadap sesuatu

4) Memfokuskan peserta didik pada sesuatu yang diinginkan

5) Membimbing peserta didik untuk menemukan atau menyimpulkan sesuatu.

d. Masyarakat belajar (learning community)

Dalam kelas CTL, penerapan asas masyarakat belajar dapat dilakukan dengan menerapkan pembelajaran melalui kelompok belajar. Peserta didik dibagi dalam kelompok-kelompok yang anggotanya bersifat heterogen, baik dilihat dari kemampuan dan kecepatan belajarnya, maupun dilihat dari bakat dan minatnya. Peserta didik dibiarkan dalam kelompoknya, mereka saling membelajarkan yang memiliki kemampuan tertentu dapat menularkan pada peserta didik yang lain (Faturrahman, 2012: 78).

e. Pemodelan (modelling)

Model pengetahuan dan keterampilan tertentu diperlukan dalam pembelajaran CTL. model yang dimaksud bisa berupa model proses belajar maupun model hasil belajar (Zulfatmi, 2018: 35). Misalnya, pendidik memberikan contoh bagaimana cara mengoperasikan sebuah alat, atau bagaimana cara melafalkan sebuah kalimat asing.

Proses pemodelan tidak terbatas pada pendidik saja, tetapi pendidik dapat memanfaatkan sejumlah peserta didik yang memiliki kemampuan. Modelling merupakan asas yang cukup penting dalam pembelajaran $C T L$, sebab melalui modelling peserta didik terhindar dari pembelajaran yang teoretis abstrak yang memungkinkan terjadinya verbalisme (Hamdayama, 2016: 139).

f. Refleksi

Refleksi adalah proses pengendapan pengalaman yang telah dipelajari yang dilakukan dengan cara mengurutkan kembali kejadian-refleksi, pengalaman belajar itu dimasukkan dalam struktur kognitif peserta didik yang akan menjadi bagian dari pengetahuan yang dimilikinya (Hamruni, 2015: 183).

Dalam proses pembelajaran CTL, setiap berakhir proses pembelajaran, pendidik memberikan kesempatan kepada peserta didik untuk merenung atau mengingat kembali apa yang telah dipelajarinya. Biarkan secara bebas peserta didik menafsirkan pengalamannya sendiri sehingga ia dapat menyimpulkan tentang pengalaman belajarnya (Rusman, 2016: 197).

g. Penilaian nyata (authentic assesment)

Penilaian nyata adalah peserta didik dievaluasi dengan cara penilaian kinerja pada tugastugas yang merupakan perwakilan dari kegiatan yang benar-benar dilakukan dalam pengaturan kehidupan nyata yang relevan (pengalaman) (Shawn M. Glynn, 2004: 53). Penilaian ini diperlukan untuk mengetahui apakah peserta didik benar-benar belajar atau tidak, apakah pengalaman belajar peserta didik memiliki pengaruh positif terhadap perkembangan intelektual mental peserta didik (Hamdayama, 2016: 140).

Pola dan Tahapan Contextual Teaching and Learning dalam Pembelajaran Pendidikan Agama Islam 
Terdapat indikator untuk mencapai kompetensi hasil belajar: (1) Peserta didik dapat menjelaskan pengertian zakat, (2) Peserta didik dapat menjelaskan macam-macam zakat, (3) Peserta didik dapat menjelaskan tata cara pelaksanaan zakat fitrah dan zakat mal, (4) Peserta didik dapat menyimpulkan tentang fungsi zakat, (5) Peserta didik mampu membuat karangan yang ada kaitannya dengan zakat.

Adapun tahapan pembelajaran Contextual Teaching and Learning untuk mencapai kompetensi yang sesuai dengan yang diharapkan pendidik adalah: pertama, pendahuluan, yaitu pendidik menjelaskan kompetensi yang harus dicapai serta manfaat dari proses pembelajaran dan pentingnya materi pelajaran yang akan dipelajari. Berikutnya, peserta didik dibagi ke dalam beberapa kelompok sesuai dengan jumlah peserta didik. Tiap kelompok ditugaskan untuk melakukan tugas tertentu: misalnya kelompok 1 dan 2 melakukan wawancara dengan pengurus takmir masjid yang berpengalaman mengelola zakat, dan kelompok 3 dan 4 melakukan wawancara ke lembaga bazis yang ada di wilayahnya. Melalui wawancara, peserta didik ditugaskan untuk mencatat berbagai hal yang ditemukan tentang pengertian, macam-macam, tata cara pengelolaan, dan fungsi zakat. Pendidik melakukan tanya jawab sekitar tugas yang harus dikerjakan oleh setiap peserta didik

Kedua, inti, yaitu, peserta didik melakukan wawancara di lapangan sesuai dengan pembagian tugas kelompok. Lalu, peserta didik mencatat hal-hal yang mereka temukan sesuai dengan alat observasi yang telah mereka tentukan sebelumnya. Berikutnya, di dalam kelas, peserta didik mendiskusikan hasil temuan mereka sesuai dengan kelompoknya masing-masing. Lalu, mereka melaporkan temuan mereka. Setiap kelompok menjawab setiap pertanyaan yang diajukan oleh kelompok yang lain.

Ketiga, penutup, yaitu, dengan bantuan pendidik, peserta didik menyimpulkan hasil wawancara sekitar masalah zakat sesuai dengan indikator hasil belajar yang harus dicapai. Pendidik menugaskan peserta didik untuk membuat karangan tentang pengalaman belajar mereka dengan tema "zakat" (Hamruri, 2009: 186-189).

\section{Penilaian dalam Pembelajaran Kontekstual}

Penilaian di dalam pembelajaran CTL dikenal dengan nama penilaian autentik (authentic assessment). Penilaian autentik dilakukan untuk mengukur penerapan pengetahuan di dalam konteks autentik. Penilaian autentik bertujuan untuk menyediakan informasi yang valid dan akurat mengenai apa yang benar-benar diketahui dan dapat dilakukan oleh peserta didik, atau tentang kualitas program pendidikan. Menurut Ratumanan (2015: 89-95), beberapa teknik penilaian yang merupakan bagian dari penilaian autentik adalah:

a. Penilaian Kinerja (performance assessment)

Penilaian kinerja dikembangkan untuk menguji kemampuan peserta didik dalam mendemonstrasikan pengetahuan dan keterampilan mengenai berbagai situasi nyata dalam konteks tertentu. Menurut Johnson dikutip dalam buku "Inovasi Pembelajaran" karya Ratumanan, dalam tugas kinerja, peserta didik mendemonstrasikan kepada audience bahwa mereka telah menguasai tujuan belajar tertentu. Penilaian kinerja dapat dipersingkat atau diperluas dalam bentuk pertanyaan terbuka (open-ended question) atau bentuk pilihan ganda (multiple choice).

Dalam pengertian luas, penilaian kinerja dapat berupa membaca, menulis, proyek, proses, pemecahan masalah, tugas analisis, atau bentuk tugas-tugas lain yang memungkinkan peserta didik untuk mendemonstrasikan kemampuannya dalam memenuhi tujuan dan hasil tertentu.

b. Portofolio (Portfolio)

Portofolio merupakan jenis penilaian autentik yang paling populer. Portofolio merupakan koleksi dari kemajuan peserta didik atau kelompok peserta didik, buku prestasi, keterampilan, dan sikap peserta didik. Portofolio tidak harus selalu berbentuk catatan atau tulisan, tetapi dapat pula berbentuk gambar, model fisik, atau alat peraga. Portofolio meliputi koleksi kemajuan peserta didik dalam kurung waktu tertentu, dapat dalam satu semester, satu tahun, atau beberapa tahun. 
c. Proyek (Project)

Proyek merupakan suatu tugas yang meminta peserta didik menghasilkan sesuatu pada topik yang berkaitan dengan kurikulum, dan tidak hanya sekedar mereproduksi pengetahuan dalam suatu tes. Proyek bermanfaat untuk mencapai tujuan pembelajaran yang mungkin sulit dicapai dengan cara lain. Johson \& Johnson dikutip dalam buku "Inovasi Pembelajaran" karya Ratumanan mengemukakan beberapa manfaat proyek, yakni:

1) Proyek memungkinkan peserta didik menjadi kreatif dalam mengintregrasikan pengetahuan dan keterampilan yang berbeda-beda.

2) Proyek memungkinkan peserta didik mendemonstrasikan dan mengklasifikasikan multiple intellingence mereka melalui penggunaan media yang bermacam-macam.

3) Proyek menghendaki peserta didik menggunakan, menggunakan, mengintegerasikan, menerapkan, dan mentransfer berbagai informasi dan keterampilan yang berbeda-beda ke dalam proyek.

4) Proyek memberikan peserta didik kesempatan untuk menformulasikan pertanyaan mereka sendiri dan kemudian mencoba menjawabnya.

d. Buku Harian dan Jurnal (Logs and Journal)

Buku harian atau jurnal merupakan alat kunci untuk memiliki dokumen peserta didik dan merefleksikan pengalaman belajar mereka. Buku harian merupakan prosedur laporan diri di mana peserta didik membuat cacatan pendek mengenai materi pelajaran yang dipelajari. Selanjutnya, jurnal merupakan prosedur laporan diri di mana peserta didik membuat cacatan naratif berisi materi pelajaran yang dipelajari. Isi jurnal dapat berupa observasi probadi, perasaan, dan opini berupa respons terhadap bacaan, peristiwa, dan pengalaman. Jurnal menyajikan suatu cara bagi peserta didik untuk merefleksikan atau mengaitkan pemikirannya dengan pemikiran sebelumnya dan kemudia pendidik menguji refleksi tersebut untuk mengetahui atau mengumpulkan informasi mengenai sejauh mana pemahaman berpikir peserta didik.

\section{KESIMPULAN}

Pembelajaran CTL (Contextual Teaching and Learning) adalah pembelajaran yang menekankan kepada proses keterlibatan peserta didik untuk dapat menemukan materi yang dipelajari dan menghubungkan dengan situasi kehidupan nyata, sehingga mendorong peserta didik untuk dapat menerapkannya dalam kehidupan mereka. Terdapat enam karakteristik pembelajaran CTL: Pembelajaran bermakna, penerapan pengetahuan, berpikir tingkat tinggi, kurikulum yang dilambangkan berdasarkan standar, reponsife terhadap kebudayaan, penilaian autentik. CTL memiliki 7 asas yang melandasi pelaksanaan proses pembelajaran dengan menggunakan model pembelajaran CTL: Konstruktivisisme, Inquiry, Bertanya, Masyarakat belajar (learning community), Pemodelan (modelling), Refleksi, dan Penilaian nyata (authentic assesment). Pembelajaran $C T L$ dalam pengajaran sangat diperlukan terutama pembelajaran dalam PAI, sebab pembelajaran ini bersifat mengajak peserta didik lebih aktif dalam pembelajaran.

\section{DAFTAR PUSTAKA}

Abdi, Muhammad Iwan. (2011) Contextual Teaching And Learning (CTL) Dalam Pembelajaran PAI. Dinamika Ilmu, vol. 11, no. 1, p. 1-9.

From https://journal.uinsi.ac.id/index.php/dinamika_ilmu/article/view/49

Akbar, Rofiq Faudy. (2015) Metode Contextual Teaching and Learning untuk Pengembangan Pembelajaran PAI. Edukasia: Jurnal Penelitian Pendidikan Islam, vol. 10, no.2, p. 211-288. From https://journal.iainkudus.ac.id/index.php/Edukasia/article/view/792

Berns, Robert G, dan Erickson, Patricia M. (2001) Contextual Teaching and Learning: Preparing Students for the New Economi, National Dissemination Center for Career and Technical Education, p. 1-9. From https://files.eric.ed.gov/fulltext/ED452376.pdf 
Depdiknas. (2002) Pendekatan Kontekstual (Contextual Teaching and Learning). Jakarta: Depdiknas.

Faturrahman, Muhammad. (2012) Belajar dan Pembelajaran (Membantu Meningkatkan Mutu Pembelajaran sesuai Standar Nasional). Yogyakarta: Teras.

Glynn, Shawn M. (2004) Contextual Teaching and Learning of Science in Elementary Schools. Journal of Elementary Science Education, vol. 16, no. 2, p. 51-63. From https://link.springer.com/article/10.1007/BF03173645

Hadi, Samsul. (2016) Pengembangan Desain Pembelajaran Dengan Model Contextual Teaching and Learning Pada Pelajaran Pendidikan Agama Islam Siswa Kelas VII Smp Negeri 2 Asembagus, El-Wasathiya: Jurnal Studi Agama, vol. 4, no. 2, p. 193 - 212.

Hamdayama, Jumanta. (2016) Metodologi Pengajaran. Jakarta: Bumi Aksara.

Hamruni. (2015) Konsep Dasar dan Implementasi Pembelajaran Kontekstual. Jurnal Pendidikan Agama Islam. vol. 12, no. 2, p. 177-188. From https://ejournal.uinsuka.ac.id/tarbiyah/index.php/jpai/article/view/862

Hamruri. (2009) Strategi dan Model-Model Pembelajaran Aktif dan Menyenangkan. Yogyakarta: Fakultas Tarbiyah UIN Sunan Kalijaga.

Harudin, dkk. (2018) Penerapan Pendekatan Contextual Teaching and Learning (CTL ) dan Pembelajaran Berbasis Kearifan Lokal untuk Meningkatkan Aktivitas Belajar Siswa Mata Pelajaran Pendidikan Agama Islam. Jurnal At-Tazakki, vol. 2, no. 1, p. 121-130. From http://jurnal.uinsu.ac.id/index.php/attazakki/article/view/1451

Hudson, Clemente Charles dan Whisler, Vesta R. (2008) Contextual Teaching and Learning for Practitioners. Systemic, Cybernetics and Informatics, vol. 6, no. 4, 54-58. From http://www.iiisci.org/journal/sci/FullText.asp?var=\&id=E668PS

Johnson, Elaine B. (2002) CTL: Contextual Teaching and Learning. California: Corwin Press. Lestari, Ade. (2017) Penerapan Contextual Teaching and Learning pada Pembelajaran Pendidikan Agama Islam. Edu Riligia. vol. 1, no. 3.

From http://jurnal.uinsu.ac.id/index.php/eduriligia/article/view/1060

M. Glynn, Shawn. (2004) Contextual Teaching and Learning of Science in Elementary Schools. Journal of Elementary Science Education, vol. 16, no.2, p. 51-63. From https://link.springer.com/article/10.1007/BF03173645

Marzuki, Ahmad. (2017) Model-Model Pembelajaran PAI Inovatif dan Kontekstual. Jurnal alGhazwah, vol. 1, no. 1, p. 103-116.

Nurhidayah, Konik Afifah. (2019) Pengembangan perangkat pembelajaran pendidikan agama Islam model Problem Based Learning dengan pendekatan Contextual Teaching and Learning untuk meningkatkan kemampuan berpikir kreatif siswa. Masters Thesis UIN Sunan Ampel Surabaya.

Parhan, Muhamad dan Sutedja, Bambang (2019) Penerapan Pendekatan Pembelajaran Kontekstual Dalam Pendidikan Agama Islam Di Universitas Pendidikan Indonesia, Tarbawi: Indonesian Journal of Islamic Education, vol. 6, no. 2, p. 114-146. From https://ejournal.upi.edu/index.php/tarbawy/article/view/20165

Purnomo, Andrean. Ma'arif, Muhammad Anas. Nihayah, Ismatun (2020) Implementasi Model Contextual Teaching And Learninguntuk Meningkatkan Prestasibelajar Pendidikan Agama Islam, The 1st International Conference on Islamic and Social Education Interdisciplinary "Transforming Multidimensial Aspects via Islamic and Social Education", p. 206-216.

Ratumanan. (2015) Inovasi Pembelajaran (Mengembangkan Kompetensi Peserta Didik secara Optimal). Yogyakarta: Ombak.

Riyanto, Yatim. (2010) Paradigma Baru Pembelajaran. Jakarta: Prenada Media Group.

Rusman. (2006) Model-Model Pembelajaran. Jakarta: PT RajaGrafindo Persada. 2016. Sanjaya, Wina. Strategi Pembelajaran (Berorientasi Standar Proses Pendidikan). Jakarta: Prenada Media. 
Saputra, Aidil. (2014) Aplikasi Metode Contextual Teaching Learning (CTL) Dalam Pembelajaran PAI, At-Ta'dib, vol. 4, no. 1, p. 14-46.

Shamsid-Deen, Ifraj, dan Smith, Bettye P. (2006) Contextual Teaching and Learning Practices in The Family anf Consumer Sciences Curriculum. Journal of Family and Consumer Sciences Education, vol. 24, no. 1, p. 14-28.

Sudirman. (2011) Interaksi dan Motivasi Belajar Mengajar. Jakarta: Raja Grafindo Persada.

Tamam, M. Badrut. (2015) Model Pembelajaran Kontekstual pada Mata Pelajaran PAI di SMP Al-Azhar Banjar Patroman. Jurnal Kependidikan, vol. 3, no. 2, p. 89-108. From http://www.ejournal.iainpurwokerto.ac.id/index.php/jurnalkependidikan/article/down $\underline{\text { load/901/740 }}$

Zulfatmi. (2018) Penerapan Contextual Teaching Learning (CTL) dalam Perkuliahan Strategi dan Metode Pembelajaran Pendidikan Agama Islam. Jurnal Mudarrisuna, vol. 8, no. 1, p. 25-45. 